\title{
Efektifitas Penggunaan Model Pembelajaran Problem Based Learning Dan Discovery Learning Berbantuan Media Gambar Terhadap Kreativitas Pada Pembelajaran Tematik Siswa Kelas 5 SD Negeri Tingkir Tengah 01 Tahun 2019/2020
}

\author{
${ }^{1}$ Raka Afada Maarif, ${ }^{2}$ Tego Prasetyo \\ Prodi Pendidikan Guru Sekolah Dasar, Universitas Kristen Satya Wacana \\ Email:1292016077@student.uksw.edu, ${ }^{2}$ tego.prasetyo@uksw.edu
}

\begin{abstract}
Abstrak. Penelitian ini bertujuan untuk mengetahui tingkat efektifitas antara model pembelajaran Problem Based Learning dan Discovery Learning dengan berbantuan media gambar terhadap kreativitas pada pembelajaran tematik kelas 5 SD. Penelitian ini menggunakan eksperimen semu (quasi experiment). Dengan desain penelitian menggunakan nonequivalent control group design. Hasil yang diperoleh melalui uji prasyarat berbantuan SPSS 25 for windows yaitu data berdistribusi normal dan homogeny. Selanjutnya melakukan uji T menggunakan Independent Sample $T$ Test diperoleh hasil dengan nilai Sig. (2-tailed) sebesar $0,000<0,05$ yang artinya $\mathrm{H}_{\mathrm{o}}$ ditolak dan $\mathrm{H}_{\mathrm{a}}$ diterima. Berdasarkan hasil yang diperoleh maka (1) terdapat perbedaan yang signifikan antara model pembelajaran Problem Based Learning dan Discovery Learning berbantuan media gambar terhadap kreativitas siswa pada pembelajaran tematik siswa kelas 5 SD, (2) terjadinya perbedaan dalam kreativitas siswa yang menunjukkan bahwa lebih berpengaruh menggunakan model pembelajaran Problem Based Learning sebesar 77,68\%. Sedangkan model pembelajaran Discovery Learning sebesar $73,15 \%$.
\end{abstract}

\section{Kata kunci: Problem Based Learning, Discovery Learning, Kreativitas Siswa}

\section{PENDAHULUAN}

Sistem Pendidikan Nasional UU RI No.20 Tahun 2003 Pasal 34 menyatakan bahwa setiap warga negara yang berusia 6 tahun dapat mengikuti program wajib belajar. Pemerintah dan pemerintah daerah menjamin terselenggaranya wajib belajar minimal pada jenjang pendidikan dasar tanpa memungut biaya.Wajib belajar merupakan tanggung jawab negara yang diselenggarakan oleh lembaga pendidikan pemerintah, pemerintah daerah, dan masyarakat.Ketentuan mengenai wajib belajar sebagaimana dimaksud pada ayat (1), ayat (2), dan ayat (3) diatur lebih lanjut dengan peraturan pemerintah.Dari pernyataan mengenai UU RI tentang sistem pendidikan nasional pasal 34 tersebut maka setiap warga negara wajib mengikuti program belajar.

Belajar merupakan suatu kegiatan yang dilakukan oleh seseorang supaya memperoleh perilaku, pengetahuan dan keterampilan yang baik. Menurut Sudjana (Rusman, 2011: 1), hakikat belajar merupakan proses interaksi yang ada di sekitar individu. Belajar juga merupakan proses melihat, mengamati dan memahami sesuatu. Sedangkan menurut Hamalik (2011: 41) belajar adalah perubahan tingkah laku sebagai kegiatan pembelajaran sangat berguna bagi kehidupan manusia dalam meningkatkan potensi diri.

Pembelajaran merupakan suatu kegiatan interaksi yang terjadi antara siswa dan guru serta sumber belajar pada suatu lingkungan belajar. Menurut Undang-Undang Sistem Pendidikan Nasional No. 20 Tahun 2003 menyatakan bahwa pembelajaran merupakan proses interaksi peserta didik dengan pendidik dan sumber belajar pada suatu lingkungan belajar. Rustaman (2011: 1) juga mengemukakan bahwa pembelajaran merupakan suatu sistem, yang terdiri atas berbagai komponen yang saling berhubungan satu dengan yang lain. Komponen tersebut meliputi tujuan, materi, metode, dan evaluasi. Sedangkan, Dimyati dan Mudjiono (Sagala, 2011: 62) pembelajaran adalah kegiatan guru secara terprogram dalam desain instruksional, untuk membuat belajar secara aktif yang menekankan pada penyediaan sumber belajar. Menurut

Rustaman

(2001:461) 
mengemukakan bahwa proses pembelajaran adalah proses yang di dalamnya terdapat kegiatan interaksi antara guru-siswa dan komunikasi timbal balik (feedback) yang berlangsung dalam situasi edukatif untuk mencapai tujuan belajar.

Dari penjelasan di atas peneliti berpersepsi bahwa proses pembelajaran memiliki peran yang sangat penting, proses pembelajaran berfokus pada kegiatan interaksi antara siswa dengan guru dalam lingkungan belajar yang di dalamnya terdapat komunikasi timbal balik untuk mencapai tujuan belajar. Peneliti juga memiliki gambaran bahwa dalam proses pembelajaran guru sangat berperan penting salah satunya mengembangkan inovasi dalam pembelajaran sehingga dapat meningkatkan mutu dan kualitas pada guru serta dapat meningkatkan perkembangan siswa sesuai dengan yang diharapkan. Proses belajar juga tidak terlepas dari pemilihan model pembelajaran yang tepat agar tujuan pembelajaran dapat tercapai dengan baik, oleh karena itu penting bagi seorang guru dalam merencanakan dan menentukan model pembelajaran yang sesuai dengan karakteristik dan keadaan siswanya. Banyak berbagai model pembelajaran diantaranya model pembelajaran Problem Based Learning dan model pembelajaran Discovery Learning. Model pembelajaran Problem Based Learning atau pembelajaran berbasis masalah terpusat pada keberhasilan siswa dalam memecahkan masalah, sedangkan Discovery Learning terpusat pada aspek penemuan.

Selain efektifitas model pembelajaran, timbul juga masalah yang terjadi karena kurangnya kreativitas siswa. Peneliti menduga hal tersebut terjadi dikarenakan kebanyakan proses pembelajaran hanya menekankan pada kemampuan berpikir dan pengetahuan (kognitif) saja dibandingkan merangsang kreativitas dalam diri siswa. Lebih lanjut peneliti juga menduga penyebab kurangnya kreativitas siswa dikarenakan fasilitas atau media belajar yang kurang dalam mendukung kreativitas siswa karena kebanyakan pembelajaran masih berfokus pada guru. Hal ini sejalan dengan Jellen dan Urban (Rachmawati dan Kurniawati, 2011: 6) yang menunjukkan rendahnya tingkat kreativitas anak indonesia, terbukti pada tingkat kreativitas anak indonesia yang menempati posisi terendah dari negara lainnya.

Dari penjelasan diatas tersebut maka media pendukung sangat berguna dalam proses pembelajaran agar dapat merangsang kreativitas siswa. Menurut Heinich yang dikutip oleh Arsyad (2011:4), media pembelajaran adalah perantara yang membawa pesan atau informasi bertujuan instruksional atau mengandung maksud-maksud pengajaran antara sumber dan penerima. Di antara media pembelajaran, media gambar lebih umum dipakai. Karena sebagian besar siswa lebih menyukai gambar daripada teks. Untuk itu peneliti ingin menggunakan media gambar sebagai subjek dalam penelitian ini. Menurut Hamalik (1994: 95), media gambar adalah segala sesuatu yang diwujudkan secara visual kedalam bentuk dua dimensi sebagai curahan ataupun pikiran yang bentuknya bermacammacam seperti lukisan, potret, slide, film, strip, opaque projektor. Media gambar digunakan agar siswa dapat mengetahui dari apa yang mereka lihat dan cenderung tidak mengkhayal apa yang tidak mereka lihat.

Dari pengamatan yang peneliti lakukan di SD Negeri Tingkir Tengah 01 menunjukkan bahwa beberapa siswa belum mampu dalam mengambil inisiatif pada saat guru memberi suatu pemasalahan, siswa hanya terpaku penjelasan guru dan apa yang guru lakukan. Hal ini membuktikan bahwa kreativitas siswa yang masih rendah. Hal lain juga terlihat pada proses belajar yang guru lakukan, dalam mengajar guru hanya mengutamakan pada aspek kognitif saja dan kurang memperhatikan aspek kreativitas siswa. Padahal kreativitas memungkinkan siswa dapat mengembangkan segala kemampuannya menilai, peka terhadap rangsangan, berani memanipulasi obyek, menguji gagasan, terampil, berani atas inisiatif sendiri, menyampaikan ide, kritik membangun (Mulyasa, 2009: 59-60). Walaupun proses belajar sudah berjalan dengan baik namun perlu memperhatikan berbagai aspek diantaranya kreativitas. Rendahnya aspek kreatifitas inilah yang perlu menjadi fokus bagi guru pada proses pembelajaran agar dapat 
menggali dan memaksimalkan potensi dalam diri siswa.

Berdasarkan penjelasan diatas, sasaran yang menjadi perhatian peneliti adalah kreativitas siswa karena dari pengamatan yang peneliti lakukan beberapa siswa masih memiliki kreativitas yang rendah. Oleh karena itu dalam penelitian ini peneliti akan mencoba menggunakan dua model pembelajaran sebagai subjek penelitian yakni model pembelajaran Problem Based Learning dan model pembelajaran Discovery Learning untuk mengetahui efektifitas dari kedua model pembelajaran tersebut terhadap kreativitas siswa.

Adapun penelitian yang dilakukan mengenai model Problem Based Learning $(P B L)$ dan Discovery Learning $(D L)$ yang dilakukan peneliti lain untuk mengetahui keefektifan kedua model tersebut diantaranya hasil penelitian yang dilakukan oleh Uswatun Hasanah (2017: 76), yang berjudul "Perbandingan Hasil Belajar Siswa Menggunakan Model Discovery Learning dengan Problem Based Learning pada Materi Gerak Melingkar". Penelitian tersebut menggunakan desain penelitian Pretest Posttest Equivalent Group Design. Berdasarkan penelitiannya diperoleh bahwa tidak terdapat perbedaan hasil belajar kognitif dan kps pada kedua model, sedangkan sikap ilmiah pada model Problem Based Learning lebih tinggi dari Discovery Learning. Sedangkan dari hasil penelitian yang diperoleh Muhammad Sifa'i (2018: 106-107), yang berjudul "Pengaruh Model Pembelajaran Discovery Learning dan Problem Based Learning Terhadap Kemampuan Pemecah Masalah Peserta Didik". Peneliti tersebut menggunakan jenis eksperimen semu (quasy eksperimental) dengan desain the matching only pretest-postest control group. Berdasarkan hasil penelitiannya model pembelajaran Problem Based Learning terhadap kemampuam pemecahan masalah menunjukkan nilai rata-rata pretest dan posttest kurang dari nilai rata-rata pretest dan posttest model pembelajaran Discovery Learning terhadap kemampuan pemecahan masalah dan dapat disimpulkan terdapat perbedaan yang signifikan antara model Discovery Learning dan model pembelajaran Problem Based Learning terhadap kemampuan pemecahan masalah pada peserta didik.

Berdasarkan penelitian tersebut maka peneliti ingin mengetahui lebih dalam mengenai keefektifan model Problem Based Learning dan Discovery Learning dengan berbantuan media gambar terhadap kreativitas siswa. Dengan penggunaan model tersebut peneliti berharap dapat mengetahui model pembelajaran yang lebih efektif dalam meningkatkan kreativitas siswa terutama siswa kelas 5 di SD Negeri Tingkir Tengah 01.

\section{METODE PENELITIAN}

Penelitian yang dilakukan adalah eksperimen semu (quasi experiment). Eksperimen semu dilakukan guna mengetahui efektifitas sebuah perlakuan terhadap karakteristik subjek yang akan diteliti. Pengumpulan data penelitian dilakukan dengan cara membagikan lembar angket yang sesuai dengan indikator kreativitas siswa pada akhir pembelajaran. Pada kisi-kisi angket kreativitas memuat beberapa komponen yaitu, Torrance (1969: 56) menggambarkan ada empat komponen kreativitas, yaitu: (1) Fleksibilitas atau keluwesan (flexibility) adalah mempunyai gagasan-gagasan yang beragam. (2) Originalitas atau keaslian (originality) yaitu mempunyai gagasan-gagasan baru untuk memecahkan persoalan. (3) Elaborasi (elaboration) yaitu mampu mengembangkan gagasan untuk memecahkan masalah secara rinci. (4) Kefasihan (fluency) yaitu mempunyai banyak gagasan dalam berbagai kategori. Teknik analisis data menggunakan uji prasyarat (uji normalitas, uji homogenitas), uji T, dan Uji Hipotesis untuk mengetahui tingkat pengaruh model pembelajaran Problem Based Learning dan Discovery Learning berbantuan media gambar terhadap kreativitas siswa.

\section{HASIL DAN PEMBAHASAN}

Penelitian ini dilakukan di SDN Tingkir Tengah 01, SDN Tingkir Lor 02, dan SDN Tingkir Tengah 02 yang berada pada kecamatan Tingkir, Kota Salatiga dan berada pada gugus yang sama. Kelas eksperimen 1 
yang diberi perlakukan menggunakan model pembelajaran Problem Based Learning, kelas eksperimen 2 diberi perlakukan menggunakan model pembelajaran Discovery Learning, dan kelas kontrol yang tidak diberikan perlakuan. Tujuan dari penelitian ini adalah untuk mengetahui apakah terdapat perbedaan efektifitas perbedaan antara model pembelajaran Problem Based Learning dan Discovery Learning berbantuan media gambar terhadap kreativitas siswa pada pembelajaran tematik kelas 5 SD .Berikut ini adalah hasil statistik deskriptif nilai angket kreativitas siswa.

\begin{tabular}{|c|c|c|c|c|c|}
\hline \multicolumn{6}{|c|}{$\begin{array}{r}\text { Tabel 1. Statistik Deskriptif } \\
\text { Descriptive Statistics }\end{array}$} \\
\hline & $\mathrm{N}$ & Minimum & Maximum & Mean & Std. Deviation \\
\hline Eksperimen 1 & 29 & 70 & 83 & 77.69 & 3.920 \\
\hline Eksperimen 2 & 32 & 62 & 83 & 73.16 & 5.341 \\
\hline Kontrol & 31 & 56 & 83 & 66.48 & 5.353 \\
\hline Valid N (listwise) & 29 & & & & \\
\hline
\end{tabular}

Berdasarkan pada tabel 2 dapat diketahui bahwa nilai rata-rata angket untuk kelas eksperimen 1 sebesar 77,69 dengan standar deviasi sebesar 3,920. Nilai rata-rata angket untuk kelas eksperimen 2 sebesar 73,16 dengan standar deviasi 5,341. Nilai rata-rata angket untuk kelas kontrol sebesar 66,48 dengan standar deviasi 5,353. Sehingga dapat disimpulkan bahwa perolehan nilai rata-rata pada kelas eksperimen 1 yang menggunakan model pembelajaran Problem Based Learning lebih besar dibandingkan kelas eksperimen 2 yang menggunakan model pembelajaran Discovery Learning.

Tabel 2. Pedoman Penilaian dan Kategori Berpikir Kreatif

\begin{tabular}{cc}
\hline $\begin{array}{c}\text { Presentase } \\
\text { Pencapaian Aspek } \\
\text { Berpikir Kreatif }\end{array}$ & $\begin{array}{c}\text { Kategori Tingkat } \\
\text { Berpikir Kreatif }\end{array}$ \\
\hline $81-100$ & Sangat Baik \\
\hline $61-80$ & Baik \\
\hline $41-60$ & Cukup \\
\hline $21-40$ & Kurang \\
\hline $0-20$ & Sangat Kurang \\
\hline
\end{tabular}

Teknik analisis data yang dipakai untuk angket yaitu analisis deskriptif presentase. Teknik ini mempunyai tujuan untuk melihat presentase tanggapan dari responden atau siswa. Berikut ini adalah rumus yang dipakai untuk menghitung persentase.

Keterangan:

$$
P=\frac{f}{N} \times 100
$$

$\mathrm{P}=$ persentase angket

$\mathrm{f}=$ frekuensi dari setiap jawaban angket

$\mathrm{N}=$ jumlah responden

Tabel 3. Persentase Angket Kreativitas pada Kelas Eksperimen 1, Eksperimen 2, dan Kontrol

\begin{tabular}{ccc}
\hline \multicolumn{3}{c}{ Persentase Angket } \\
\hline $\begin{array}{c}\text { Kelas } \\
\text { Eksperimen } \\
\mathbf{1}\end{array}$ & $\begin{array}{c}\text { Kelas } \\
\text { Eksperimen } \\
\mathbf{2}\end{array}$ & $\begin{array}{c}\text { Kelas } \\
\text { Kontrol }\end{array}$ \\
\hline $77,68 \%$ & $73,15 \%$ & $66,48 \%$ \\
\hline
\end{tabular}

Berdasarkan hasil rata-rata uji kemampuan berpikir kreatif siswa diperoleh data bahwa kelas eksperimen 1 lebih tinggi yaitu dengan rata-rata nilai 77,69 dibandingkan dengan kelas eksperimen 2 dengan memperoleh rata-rata nilai sebesar 73,16 dan dengan kelas kontrol yang mendapatkan rata-rata nilai sebesar 66,48 . Hal ini menunjukkan bahwa perlakuan yang dilakukan pada kelas eksperimen 1 yang menggunakan model pembelajaran Problem Based Learning lebih efektif daripada kelas eksperimen 2 yang menggunakan model Discovery Learning serta kelas kontrol yang tidak diberikan perlakuan apapun.

Dilihat dari persentase angket kreativitas, bahwa kelas eksperimen 1, eksperimen 2, dan kontrol masuk ke dalam kategori "baik". Akan tetapi, hasil persentase yang lebih tinggi yaitu kelas eksperimen 1 yang menggunakan model pembelajaran Problem Based Learning.

Tabel 4. Uji Normalitas Kelas Eksperimen 1, Eksperimen 2, dan Kontrol

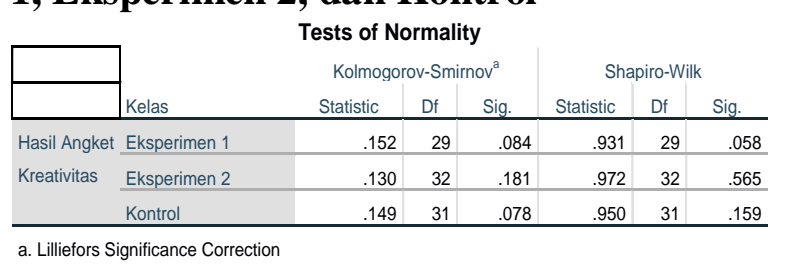


Berdasarkan pada tabel 4, maka dapat dilihat uji normalitas angket kelas eksperimen 1, eksperimen 2, dan kontrol dilihat pada kolom Shapiro wilk dengan software SPSS 25 for windows dengan hasil nilai signifikasi > 0,05 maka hasil data dapat dikatakan berdistribusi normal.

\section{Tabel 5. Uji Homogenitas Kelas Eksperimen 1, Eksperimen 2, dan Kontrol Test of Homogeneity of Variance}

\begin{tabular}{ll|r|r|r|r} 
& Levene Statistic & df1 & df2 & Sig. \\
\hline Hasil Angket & 1.076 & 2 & 89 & .345 \\
\cline { 2 - 6 } Kreativitas & Based on Mean & 1.085 & 2 & 89 & .342 \\
\cline { 2 - 6 } & Based on Median & 1.085 & 2 & 81.253 & .343 \\
\cline { 2 - 6 } & Based on Median and with adjusted df & 1.087 & 2 & 89 & .342 \\
\cline { 2 - 6 } & Based on trimmed mean & &
\end{tabular}

Berdasarkan tabel 5, menunjukkan hasil homogenitas Levene's Test dengan rata-rata (Based on Mean) sehingga menunjukkannilai Sig. 0,345 > 0,05 yang artinya bahwa kelas eksperimen 1, eksperimen 2 dan kontrol hasil data nilai angket kreativitas siswa adalah mempunyai varian yang sama (homogen).

Tabel 6. Uji $T$ menggunakan Independent Sample T Test

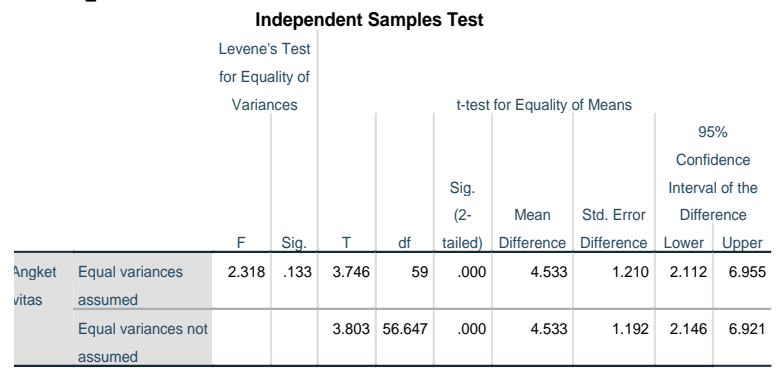

Berdasarkan hasil uji $\mathrm{T}$ menggunakan Independent Sample T Test pada kolom Equal variances assumed yang diketahui bahwa $\mathrm{t}$ hitung angket kreativitas siswa adalah 3,746 dengan nilai Sig. (2-tailed) sebesar 0,000. Terdapat juga perbedaan rata-rata pada kolom Mean Difference sebesar 4,533. T tabel yang terdapat dari perolehan data di atas adalah 2,00030.

\section{Uji Hipotesis}

Berdasarkan data yang diperoleh pada analisis uji $\mathrm{T}$ menggunakan Independent Sample $T$ Test yang tertera pada tabel 6, langkah selanjutnya yang dilakukan adalah melakukan uji hipotesis. Uji hipotesis dilakukan guna mengetahui apakah hipotesis diterima atau ditolak. Hipotesis pada penelitian ini adalah sebagai berikut.
$\mathrm{H}_{\mathrm{o}}$ : Tidak terdapat perbedaan yang signifikan antara model pembelajaran Problem Based Learning dan Discovery Learning terhadap kreativitas siswa.

$\mathrm{H}_{\mathrm{a}}$ : Terdapat perbedaan yang signifikan antara model pembelajaran Problem Based Learning dan Discovery Learning terhadap kreativitas siswa.

Kriteria pengambilan keputusan adalah sebagai berikut:

1. Menggunakan koefisien Sig. dengan ketentuan:

a. Jika nilai sig. hitung (probabilitas) < 0,05 maka $\mathrm{H}_{\mathrm{o}}$ ditolak.

b. Jika nilai sig. hitung (probabilitas) > 0,05 maka $\mathrm{H}_{\mathrm{o}}$ diterima.

2. Menggunakan koefisien $t$ hitung dengan ketentuan:

a. Jika koefisien $t$ hitung $>\mathrm{t}$ tabel maka $\mathrm{H}_{\mathrm{o}}$ ditolak.

b. Jika koefisien $t$ hitung $<\mathrm{t}$ tabel maka $\mathrm{H}_{\mathrm{o}}$ diterima.

Berdasarkan hasil perhitungan hipotesis dengan menggunakan Independent Sample $T$ Test terdapat nilai signifikansi yaitu 0,000 yang berarti bahwa lebih kecil dari 0,05 $(0,000$ $<0,05)$. Dari uji T yang menunjukkan bahwa t hitung $>\mathrm{t}$ tabel yaitu sebesar 3,746 $>2,00030$ dengan nilai signifikasi sebesar $0,000<0,05$ sehingga dapat dinyatakan bahwa $\mathrm{H}_{\mathrm{o}}$ ditolak dan $\mathrm{H}_{\mathrm{a}}$ diterima. Berdasarkan hasil tersebut, maka terdapat pengaruh yang signifikan pada penerapan menggunakan model pembelajaran Problem Based Learning dan Discovery Learning berbantuan media gambar terhadap kreativitas siswa.

\section{KESIMPULAN}

Berdasarkan hasil uji yang telah dilakukan baik penelitian dan pembahasan uji dapat diambil kesimpulan bahwa hasil angket kreativitas dalam penerapan atau pemberian perlakuan kepada siswa kelas 5 menggunakan model Problem Based Learning SDN Tingkir Tengah 1 terbukti lebih efektif dibandingkan hasil angket kreativitas dengan penerapan atau pemberian perlakuan pembelajaran menggunakan model Discovery Learning SDN Tingkir Lor 2 terhadap peningkatan berpikir 
kreatif. Efektifitas hasil angket kreativitas penerapan atau pemberian perlakuan pembelajaran menggunakan model Problem Based Learning dapat dibuktikan dengan hasil uji hipotesis yang diperoleh dari uji Independent Sample T-Test yang membuktikan bahwa hasil nilai yang diperoleh yaitu signifikansi 2-tailed sebesar 0,000 > 0,05 . Sehingga berdasarkan hasil data tersebut maka memperoleh kesimpulan bahwa $\mathrm{H}_{0}$ ditolak dan $\mathrm{H}_{\mathrm{a}}$ diterima yang artinya terdapat perbedaan berpikir kreatif yang signifikan dalam penerapan atau pemberian perlakuan pembelajaran menggunakan model Problem Based Learning dan menggunakan model Discovery Learning terhadap perbandingan angket kreativitas pada peserta didik kelas 5 SD.

Hal ini juga ditunjukkan berdasarkan uji prasyarat yang telah dilakukan yaitu uji normalitas, uji homogenitas dan uji t. Hasil uji normalitas angket pada kelas eksperimen 1, eksperimen 2 dan kontrol menggunakan Shapiro-Wilk dengan SPSS 25 for windows nilai signifikan $>0,05$ maka data dikatakan berdistribusi normal. Hasil homogenitas Levene's Test dengan rata-rata (Based on Mean) sehingga menunjukkan nilai Sig. 0,345 $>0,05$ yang artinya bahwa kelas eksperimen 1 , eksperimen 2 dan kontrol hasil data nilai angket kreativitas siswa adalah mempunyai varian yang sama (homogen). Kemudian hasil uji T menggunakan Independent Sample T Test terdapat nilai signifikansi yaitu 0,000 yang berarti bahwa lebih kecil dari 0,05 $(0,000<$ 0,05). Dari uji T yang menunjukkan bahwa $\mathrm{t}$ hitung $>\mathrm{t}$ tabel yaitu sebesar 3,746 $>2,00030$ dengan nilai signifikasi sebesar $0,000<0,05$ sehingga dapat dinyatakan bahwa $\mathrm{H}_{\mathrm{o}}$ ditolak dan $\mathrm{H}_{\mathrm{a}}$ diterima. Berdasarkan hasil tersebut, maka terdapat pengaruh yang signifikan pada penerapan menggunakan model pembelajaran Problem Based Learning dan Discovery Learning berbantuan media gambar terhadap kreativitas siswa pada pembelajaran tematik siswa kelas 5 SD. Dilihat dari persentase angket kreativitas, bahwa kelas eksperimen 1, eksperimen 2, dan kontrol masuk ke dalam kategori "baik". Akan tetapi, hasil persentase yang lebih tinggi yaitu kelas eksperimen 1 yang menggunakan model pembelajaran Problem Based Learning.

\section{SARAN}

Penelitian ini dapat digunakan digunakan sebagai referensi dalam penggunaan model pembelajaran berbasis masalah yaitu model Problem Based Learning dan Discovery Learning dalam pembelajaran tematik terhadap pengaruh berpikir kreatif.

\section{UCAPAN TERIMA KASIH}

Terima kasih kepada semua pihak yang telah membantu dalam penyusunan artikel ini sehingga artikel dapat selesai dengan baik.

\section{DAFTAR PUSTAKA}

Arsyad, Azhar. (2011). Media Pembelajaran. Jakarta: Raja Grafindo Persada.

Depdiknas. (2003). Undang-undang RI No.20 tahun 2003: tentang sistem pendidikan nasional.

Hamalik, O. (2011). Proses Belajar Mengajar. Jakarta: Bumi Aksara.

Hamalik. (1994). Media Pendidikan. Bandung: Citra Aditya Bakti.

Hasanah, U. (2017). Perbandingan Hasil Belajar Siswa Menggunakan Model Discovery Learning dengan Problem Based Learning pada Materi Gerak Melingkar.

Mulyasa, E, (2009). Praktik Penelitian Tindakan Kelas. Bandung: PT. Remaja Rosdakarya.

Rachmawati, Y, \& Kurniawati, E. (2011). Strategi Pengembangan Kreativitas Pada Anak Usia Taman Kanakkanak. Jakarta: Kencana Preanada Media.

Rusman. (2011). Model-Model Pembelajaran Mengembangkan Profesionalisme Guru. Jakarta: PT. Rajagrafindo Persada.

Rustaman, A. (2011). Membangun Literasi Sains Peserta Didik. Bandung: Humaniora.

Rustaman, N. (2001). Ilmu dan Aplikasi Pendidikan. Bandung: Inperial Bakti Utama. 
Sagala, S. (2011). Konsep dan Makna Pembelajaran. Bandung: Alfabeta.

Sifa'i, M. (2018). Pengaruh Model Pembelajaran Discovery Learning Dan Model Pembelajaran Problem Based Learning Terhadap Kemampuan Pemecahan Masalah Peserta Didik (Doctoral dissertation, UIN Raden Intan Lampung). 